\title{
EVALUATION OF IAA AND PHAs PRODUCTION BY CHROMIUM RESISTANT BACTERIAL ISOLATES
}

\author{
S. Pattnaik ${ }^{1}$, D. Dash ${ }^{2}$, D.P. Samantaray ${ }^{1 *}$
}

${ }^{1}$ Department of Microbiology, CBSH, OUAT, Bhubaneswar-3, Odisha, India

${ }^{2}$ Department of Botany, CBSH, OUAT, Bhubaneswar-3, Odisha,

Received - December 21, 2017; Revision - February 17, 2018; Accepted - April 29, 2018

Available Online - June 20, 2018

DOI: http://dx.doi.org/10.18006/2018.6(3).466.471

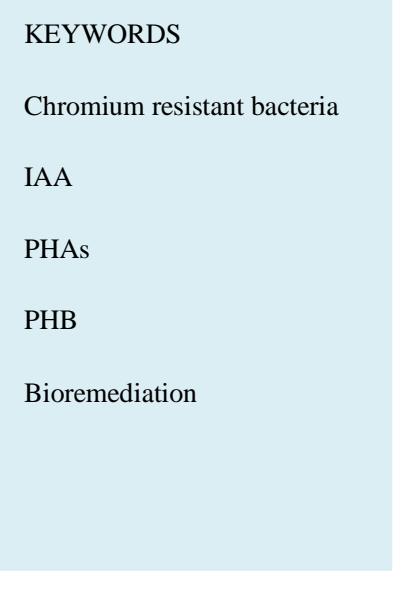

\begin{abstract}
Extensive chromite mining activities have generated huge amount of toxic hexavalent chromium $\mathrm{Cr}$ (VI), which persists in the soil for many years. Long term accumulation of $\mathrm{Cr}(\mathrm{VI})$ in the soil decreases crop productivity in adjoining farming land. On account of that, 14 chromium resistant bacteria (CRB) were subjected to Indole Acetic Acid (IAA) and Polyhydroxyalkanoates (PHAs) Production. Bacterial strains such as Bacillus sp. CTSI-07, Enterobacter sp. CTWI-06 and Acinetobacter sp. CTWI-07 were producing 24,114 and $106 \mu \mathrm{g} / \mathrm{ml}$ of IAA respectively. In addition, these bacterial isolates produced 0.75, 0.30 and $0.42 \mathrm{~g} / \mathrm{l}$ of PHAs under submerged fermentation process. Moreover, higher amount of PHAs production $(21.42 \%)$ was exhibited by Bacillus sp. CTSI-07. The extracted biopolymer is polyhydroxybutyrate (PHB) (most common homopolymer of PHAs) as revealed from structural characterization. As these bacterial strains have the capability to produce IAA and PHAs, which may be utilized for long term bioremediation of $\mathrm{Cr}(\mathrm{VI})$ in chromium contaminated soil as well as to maintain soil fertility.
\end{abstract}

* Corresponding author

E-mail: dpsamantaray@yahoo.com (Dr. Devi Prasad Samantaray)

Peer review under responsibility of Journal of Experimental Biology and Agricultural Sciences.

Production and Hosting by Horizon Publisher India [HPI] (http://www.horizonpublisherindia.in/).

All rights reserved.
All the article published by Journal of Experimental Biology and Agricultural Sciences is licensed under a Creative Commons Attribution-NonCommercial 4.0 International License Based on a work at www.jebas.org.

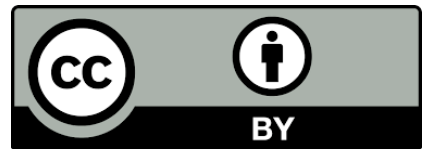




\section{Introduction}

Extensive chromite mining activities have generated huge amount of toxic waste that causes environmental pollution and public health hazard. These waste material contains a wide array of toxic metal predominantly hexavalent chromium $\mathrm{Cr}(\mathrm{VI})$, which persists in the soil for many years (Samantaray \& Mishra, 2012). Long term accumulation of $\mathrm{Cr}(\mathrm{VI})$ in the soil decreases crop productivity in adjoining farming land and can effectively impact on the microbial diversity (Yu et al., 2014). As the conventional methods for treatment of $\mathrm{Cr}(\mathrm{VI})$ are not environmental friendly, thus it is imperative to look into economic and ecofriendly alternatives. In this context, the prime concern is to reclaim and restore soil properties through the process of microbial bioremediation (Upadhyay et al., 2016). Microbes like bacteria are playing a vital role in maintaining physical and chemical structure of soil as well as its fertility (Ahemad, 2015). Bacteria respond quickly and are sensitive to subtle environmental changes; as a matter of fact, they have been considered as bio-indicators of soil texture (Valverde et al., 2011).

Bacterial strains showing higher tolerance or resistance to $\mathrm{Cr}(\mathrm{VI})$ as well as nitrogen fixation, phosphate and potassium solubilization (NPK) capability are the potential candidate for bioremediation of $\mathrm{Cr}(\mathrm{VI})$ contaminated soil (Ahemad, 2015). In addition to $\mathrm{Cr}(\mathrm{VI})$ detoxification, chromium resistant bacterial strains are also increasing nutrient availability of chromium contaminated soils (Pattnaik et al., 2017). In this regard, several studies have reported the utilization of plant growth-promoting bacteria (PGPB) that solubilize phosphate and synthesize growth-promoting substances such as indoleacetic acid (IAA) can be applied for bioremediation of metal-contaminated soil (Yu et al., 2014; Pattnaik et al., 2017; Patel et al., 2017). Application of PGPB for $\mathrm{Cr}(\mathrm{VI})$ bioremediation not only increase NPK and IAA availability in chromium contaminated soil but also stimulate seed germination (Yu et al., 2014), seedling roots (Patten \& Glick, 2002) and inhibition of phytopathogens (Haas \& Défago, 2005). Additionally, utilization of PGPB strains with PHAs synthesizing ability for reclamation of chromium contaminated soil may be an added advantage. PHAs are the carbon and energy storage granule present in the cytosol of the bacteria (Mohapatra et al., 2014) and enhances survivability of cells during unfavorable environmental conditions such as carbon starvation, exposure to radiation, desiccation, toxic metals \& oxidants (Mohapatra et al., 2016; Koller, 2017). This may increase the shelf life period of bacterial bioremediation of $\mathrm{Cr}(\mathrm{VI})$ in chromium contaminated soil. In light of above, the present research is aimed to study the IAA and PHAs production by $\mathrm{Cr}(\mathrm{VI})$ resistant or tolerant bacteria isolated from Sukinda mining area.

\section{Materials and Methods}

\subsection{Selection of source organism}

In preceding work 14 chromium resistant (up to $3500 \mathrm{ppm}$ ) bacteria (CRB) were isolated from the soil, sediment \& water samples of Sukinda mining area and preserved in glycerol stock at $-80^{\circ} \mathrm{C}$. In the present study, these bacterial isolates were revived in the Luria Bertani (LB) agar medium and subjected to Indole Acetic Acid (IAA) and Polyhydroxyalkanoates (PHAs) production. All the culture media and chemicals used in the research work were procured from HiMedia Laboratories Pvt. Ltd. Moreover, the standard and organic solvents used in this research work were procured from Merck bioscience and Sigma-Aldrich chemicals respectively.

\subsection{Estimation of IAA production by CRB}

IAA production by the $\mathrm{Cr}(\mathrm{VI})$ resistant bacterial strains was carried out using the Salkowski's method (Mohite, 2013). Screened bacterial isolates were grown in peptone water (Himedia, India) and incubated at $30^{\circ} \mathrm{C}$ for 4 days. After incubation, the cultivated medium was centrifuged at $10000 \mathrm{rpm}$ for $12 \mathrm{~min}$. One $\mathrm{ml}$ of supernatant was collected and mixed with Salkowski reagent (2\% $0.5 \mathrm{M} \mathrm{FeCl}_{3}$ in $35 \%$ $\mathrm{HCLO}_{4}$ ), kept at room temperature. Then, the quantitative estimation of IAA was conducted by measuring optical density at $540 \mathrm{~nm}$ after 30 min and 120 min intervals.

\subsection{Screening of CRB for PHAs production}

Sudan black B staining was conducted for detection of presence of the PHAs granule in cytoplasm of the bacterial cells (Mohapatra et al., 2015). Before screening, the isolates were induced to accumulate PHAs by growing in the growth medium (GM) that contained Lglutamic acid $\left(3.8 \mathrm{~g} / \mathrm{L}^{-1}\right)$, malic acid $\left(2.7 \mathrm{~g} / \mathrm{L}^{-1}\right)$, yeast extract $(2.0 \mathrm{~g} / \mathrm{L}$ $\left.{ }^{1}\right), \mathrm{KH}_{2} \mathrm{PO}_{4}\left(0.5 \mathrm{~g} / \mathrm{L}^{-1}\right), \mathrm{K}_{2} \mathrm{HPO}_{4}\left(0.5 \mathrm{~g} / \mathrm{L}^{-1}\right),\left(\mathrm{NH}_{4}\right)_{2} \mathrm{SO}_{4}\left(0.8 \mathrm{~g} / \mathrm{L}^{-1}\right), \mathrm{Mg}$ $\mathrm{SO}_{4} .7 \mathrm{H}_{2} \mathrm{O}\left(0.2 \mathrm{~g} / \mathrm{L}^{-1}\right), \mathrm{CaCl}_{2} .2 \mathrm{H}_{2} \mathrm{O}\left(0.053 \mathrm{~g} / \mathrm{L}^{-1}\right), \mathrm{MnSO}_{4} .5 \mathrm{H}_{2} \mathrm{O}(0.001$ $\left.\mathrm{g} / \mathrm{L}^{-1}\right), \mathrm{NaCl}\left(5.0 \mathrm{~g} / \mathrm{L}^{-1}\right)$, nicotinic acid $\left(1.0 \mathrm{mg} / \mathrm{L}^{-1}\right)$, thiamine $(1.0$ $\left.\mathrm{mg} / \mathrm{L}^{-1}\right)$, biotine $\left(0.01 \mathrm{mg} / \mathrm{L}^{-1}\right)$, glucose $\left(10.0 \mathrm{~g} / \mathrm{L}^{-1}\right)$ medium for $24 \mathrm{~h}$. The bacterial cells were stained with $3 \%$ Sudan black B solution for $10 \mathrm{~min}$ and decolourized by xylene. Then, the bacteria cells were stained with counter stain safranin for 10 seconds and observed under oil immersion microscope (Leica DM5000B). Further, the bacterial cells were again subjected to Nile red staining (Maity et al., 2017) for confirmation of PHAs granule in the cytoplasm.

\subsection{PHAs production by CRB}

The selected bacterial strains were subjected for PHAs production by submerged fermentation process. One-stage batch cultivation in a shake flask method was carried out for PHAs production (Mohapatra et al., 2017a). Bacterial isolates were grown in the $\mathrm{GM}$ at $37^{\circ} \mathrm{C}$ with $120 \mathrm{rpm}$ for 96 hours. Cell biomass (DCW) was then harvested by centrifugation at $6500 \mathrm{~g}, 10 \mathrm{~min}$ and dried at $50^{\circ} \mathrm{C}$. Dried cell biomass was treated with sodium hypochlorite to digest the non-PHAs materials. The mixture was then centrifuged and subsequently washed twice with acetone, methanol 
and diethyl ether (1:1:1) to remove sodium hypochlorite and debris. The partially purified PHAs was dissolved in boiling chloroform to remove the remaining organic solvents and the amount of PHAs was quantified using the formula: $\%$ of PHAs production $=($ Weight of PHAs $/$ Weight of dry cell biomass) $\times 100$.

\subsection{Characterization of PHAs by FTIR Analysis}

The functional group of extracted PHAs was identified by Fourier transform infrared (FTIR) spectroscopic analysis. Briefly, $2 \mathrm{mg}$ of extracted PHAs film was placed on Attenuated Total Reflectance (ATR) diamond based plate and the IR-spectrum was recorded using a single beam spectrometer (Perkin-Elmer RX I) between wave numbers of 4000 and $400 \mathrm{~cm}^{-1}$ (Dash et al., 2013).

\section{Results and Discussion}

\subsection{IAA production by $\mathrm{Cr}(\mathrm{VI})$ resistant bacteria}

Contamination of soil with toxic metal chromium can transform the soil micro-flora and their metabolic activity. These contaminated soils are deficient in several growth promoting nutrients and causes stress for plants (Upadhyay et al., 2017). Thus, it is the need of the hour to restore soil properties as well as plant growth using microbes. As toxic metal tolerance is one of the vital factors for utilization of native micro-flora in bioremediation. Thus, estimation of $\mathrm{Cr}(\mathrm{VI})$ tolerance of 14 bacterial isolates has been carried out in previous study of Pattnaik et al., (2017). In present study, these bacterial isolates were subjected to IAA production using both qualitative and semi-qualitative methods. Among all, bacterial isolates such as Bacillus sp. CTSI-07, Enterobacter sp. CTWI-06 and Acinetobacter sp. CTWI-07 produced approximately $24 \mu \mathrm{g} / \mathrm{ml}, 114 \mu \mathrm{g} / \mathrm{ml}$ and $106 \mu \mathrm{g} / \mathrm{ml}$ of IAA respectively (Figure 1; Table 1). In contrast to findings of present study, Upadhaya et al., (2017) reported production of IAA (56.95 $\mu \mathrm{g} / \mathrm{ml}$ ) by the chromium resistant bacteria Bacillus sp. MNU16 isolated from contaminated coal mining soil. Similar IAA producing metal tolerant bacteria such as Pantoea stewartii strain ASI11, Microbacterium arborescens strain HU33 and Enterobacter sp. strain HU38 were also isolated from rhizospheric soil of $P$. juliflora (Khan et al., 2015). Thus, utilization of these metal resistant bacteria for bioremediation can overcome toxic effect of $\mathrm{Cr}(\mathrm{VI})$ as well as increase plant growth (Hansda et al., 2014; Sobariu et al.,
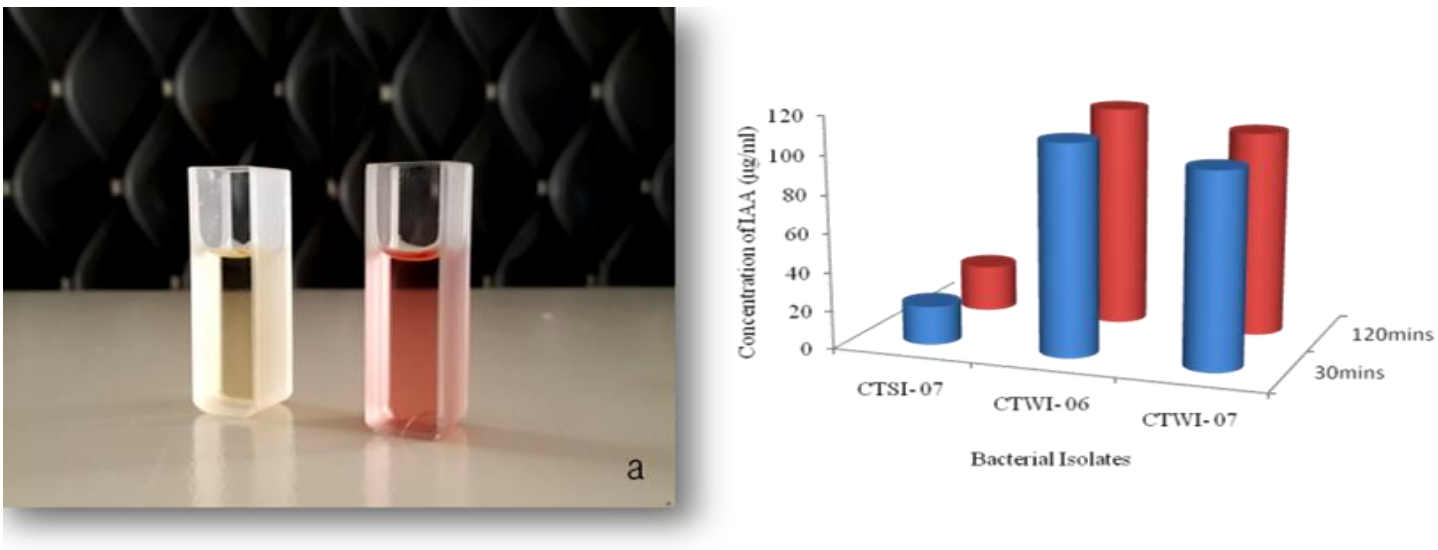

Figure 1 (a) IAA (b) production by $\mathrm{Cr}(\mathrm{VI})$ resistant bacterial isolates.

Table 1 IAA and PHAs production by CRB

\begin{tabular}{|c|c|c|c|c|c|}
\hline Isolates Code & $\begin{array}{c}\text { IAA } \\
\text { Production } \\
(\mu \mathrm{g} / \mathrm{ml})\end{array}$ & $\begin{array}{c}\text { PHAs Production } \\
(\mathrm{g} / \mathrm{l})\end{array}$ & Isolates Code & $\begin{array}{c}\text { IAA } \\
\text { Production } \\
(\mu \mathrm{g} / \mathrm{ml})\end{array}$ & $\begin{array}{c}\text { PHAs Production } \\
(\mathrm{g} / \mathrm{l})\end{array}$ \\
\hline CTSI-01 & - & - & CTWI-01 & - & - \\
\hline CTSI-02 & - & - & CTWI-02 & - & - \\
\hline CTSI-03 & - & - & CTWI-03 & - & - \\
\hline CTSI-04 & - & - & CTWI-04 & - & - \\
\hline CTSI-05 & - & - & CTWI-05 & - & - \\
\hline CTSI-06 & - & - & CTWI-06 & $+/ 114 \mu \mathrm{g} / \mathrm{ml}$ & $+/ 0.30 \mathrm{~g} / \mathrm{l}$ \\
\hline CTSI-07 & $+/ 24 \mu \mathrm{g} / \mathrm{ml}$ & $+/ 0.75 \mathrm{~g} / 1$ & CTWI-07 & $+/ 106 \mu \mathrm{g} / \mathrm{ml}$ & $+/ 0.42 \mathrm{~g} / 1$ \\
\hline
\end{tabular}

Journal of Experimental Biology and Agricultural Sciences http://www.jebas.org 
2016) in the chromium contaminated soil.

\subsection{PHAs production by $\mathrm{Cr}(\mathrm{VI})$ resistant bacteria}

Interestingly, these three chromium resistant and IAA producing bacterial strains viz., Bacillus sp. CTSI-07, Enterobacter sp. CTWI06, and Acinetobacter sp. CTWI-07 accumulated PHAs granule in their cytosol as confirmed by both Sudan black and Nile red staining method (Figure 2). Furthermore, Bacillus sp. CTSI-07, Enterobacter sp. CTWI-06 and Acinetobacter sp. CTWI-07 produced 0.75, 0.30 and $0.42 \mathrm{~g} / \mathrm{l}$ of PHAs from 3.50, 2.81, $2.55 \mathrm{~g} / \mathrm{l}$ of cell biomass respectively. Moreover, higher amount of PHAs production (21.42\%) by Bacillus sp. CTSI-07 (Table 1). This is the first report giving insight on non-growth associated PHAs production by the chromium resistant and IAA producing bacterial strains. David et al., (2015) reported that, $21.43 \%$ of PHB (most common homopolymer of PHAs) production by the metal tolerant bacteria Pseudomonas aeruginosa under nitrogen stress condition. Similarly, 80.94\%, 69.01\%, 61\%, $70 \%$ and $96.25 \%$ of PHAs production by Lysinibacillus sp. 3HHX, Bacillus subtilis, Bacillus megateriumuyuni S29 and Enterobacter aerogenes 12Bi were also reported earlier (Ceyhan \& Ozdemir, 2011; Contreras et al., 2013; Mohapatra et al., 2015; Mohapatra et al., 2016;
Mohapatra et al., 2017b). The unbalanced nutrient condition (carbon: nitrogen) creates selective pressure (Mohapatra et al., 2016) played a vital role in accumulation of PHAs granules in the cytosol of these bacteria. PHAs are the carbon and energy storage granule found in a wide array of bacteria (Mohapatra et al., 2014) and enhances survivability of cells during unfavorable environmental conditions such as carbon starvation, exposure to radiation, desiccation, toxic metals \& oxidants (Mohapatra et al., 2016; Koller, 2017). As a matter of fact, utilization of these metal resistant, IAA and PHAs producing bacteria strains for detoxification of $\mathrm{Cr}(\mathrm{VI})$ may increase the shelf life period of bioremediation.

\subsection{Characterization of PHAs by FTIR analysis}

The extracted PHAs was characterized by advanced analytical technologies to elucidate its chemical structure. IR spectra showed six intense absorption bands at 1379.38, 1261.74, 1226.8, 1130.79, 1054.71 and $976.55 \mathrm{~cm}^{-1}$ corresponding to $\mathrm{C}-\mathrm{O}$ stretch, C-N stretch and $=\mathrm{C}-\mathrm{H}$ bond respectively. However, the high intense absorption band at $1719.74 \mathrm{~cm}^{-1}$ corresponding to $(\mathrm{C}=\mathrm{O}$ stretch $)$ ester carbonyl group of PHB (Figure 3). This is the most common homopolymer of PHAs. Similar high intense absorption band such as $1736 \mathrm{~cm}^{-1}$ and
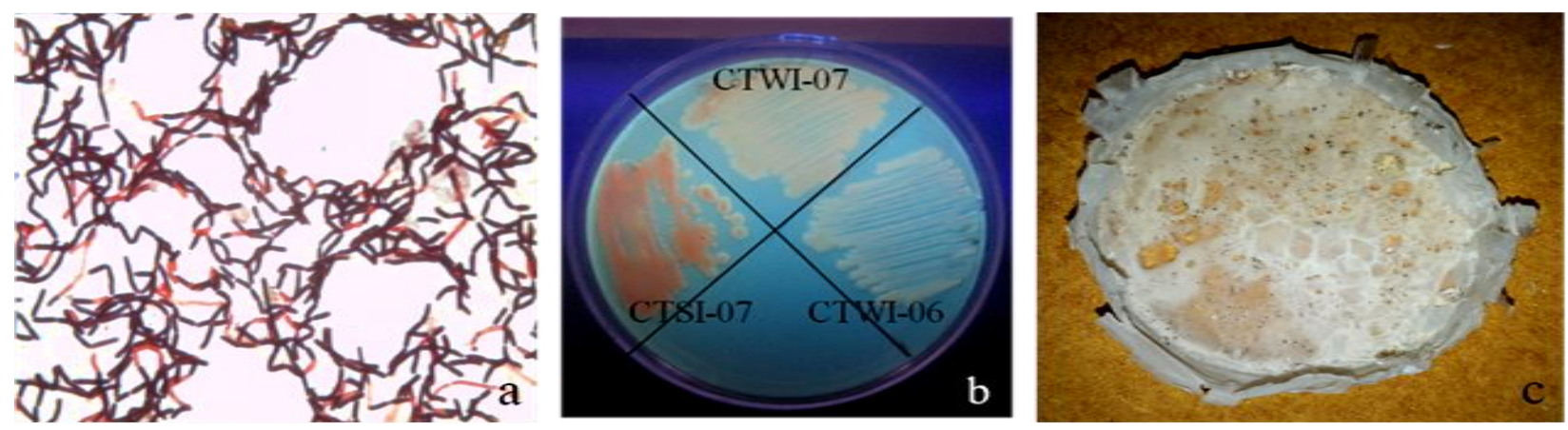

Figure 2 Bacterial isolates under (a) Sudan black, (b) Nile red staining and (c) PHB production.

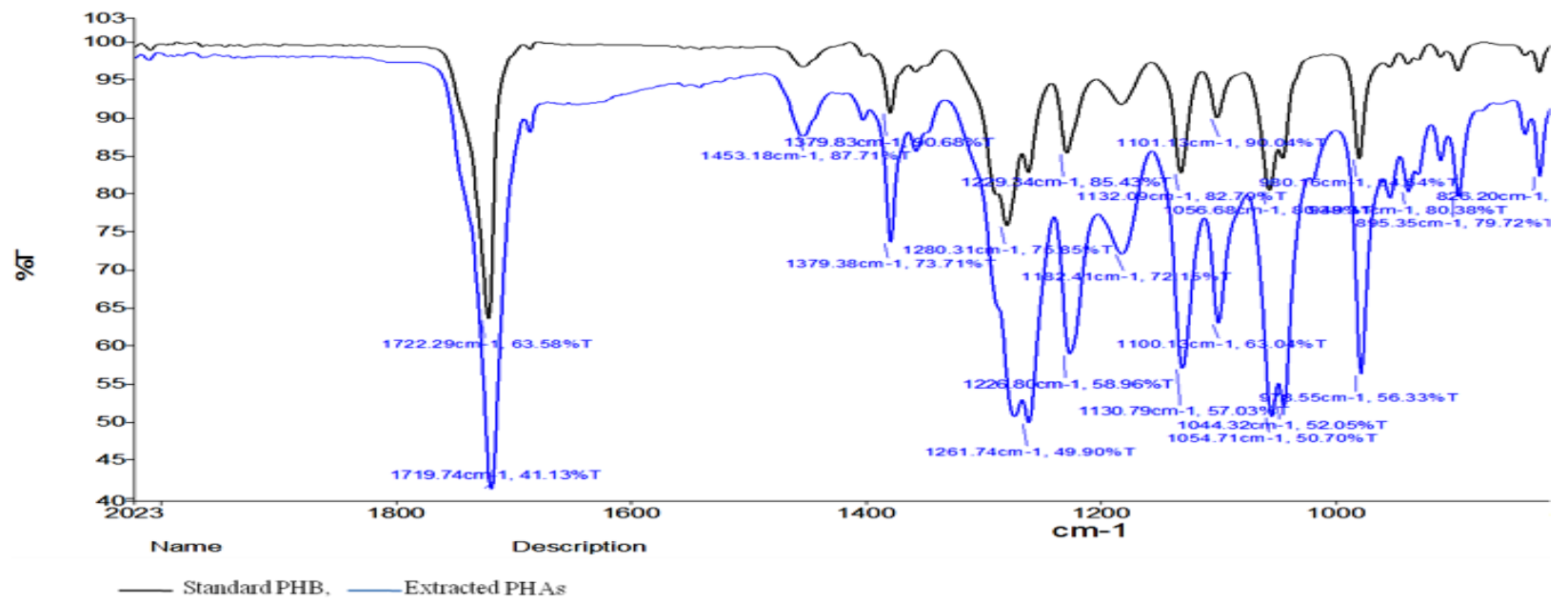

Figure 3 FTIR spectra signal peak at $1719.74 \mathrm{~cm}^{-1}$ depicting functional group of PHB.

Journal of Experimental Biology and Agricultural Sciences http://www.jebas.org 
$1711 \mathrm{~cm}^{-1}$ depicting the $(\mathrm{C}=\mathrm{O}$ stretch) ester carbonyl group of $\mathrm{PHB}$ were also reported by previous workers (Mohapatra et al., 2015; Mohapatra et al., 2017a). Thus, the biopolymer produced by the metal resistant bacteria is PHB as revealed from structural characterization.

\section{Conclusion}

In conclusion, the chromium resistant bacterial isolates such as Bacillus sp. CTSI-07, Enterobacter sp. CTWI-06 and Acinetobacter sp. CTWI-07 have the capability to produce IAA and PHB. These metal resistant bacteria can easily overcome toxic effect of $\mathrm{Cr}(\mathrm{VI})$ during bioremediation as well as increase plant growth in the chromium contaminated soil. Moreover, due to their PHAs synthesis ability, they can survive for longer period in unfavorable environmental conditions, which may increase the shelf life period of bioremediation.

\section{Acknowledgments}

The authors are thankful to of the Science and Technology Department, Government of Odisha, Bhubaneswar for financial support. Moreover, the authors are also thankful to Central Instrumentation Facility, OUAT, Bhubaneswar for providing laboratory facilities to conduct the research work.

\section{Conflict of Interest}

Authors would hereby like to declare that there is no conflict of interests that could possibly arise.

\section{References}

Ahemad M (2015) Enhancing phytoremediation of chromium-stressed soils through plant-growth-promoting bacteria. Journal of Genetic Engineering and Biotechnology13: 51-58.

Ceyhan N, Ozdemir G (2011) Poly- $\beta$-hydroxybutyrate (PHB) production from domestic wastewater using Enterobacter aerogenes 12Bi strain. African Journal of Microbiology Research 5: 690-702.

Contreras AR, Koller M, Dias MMD, Calafell-Monfort M, Braunegg G, Marqués-Calvo MS (2013) High production of poly (3hydroxybutyrate) from a wild Bacillus megaterium bolivianstrain. Journal of Applied Microbiology 114: 1378-1387.

Dash HR, Mangwani N, Das S (2013) Characterization and potential application in mercury bioremediation of highly mercury resistant marine bacterium Bacillus thuringiensis PW-05. Environmental Science and Pollution Research 21: 2642-2653.

David C, Arivazhagan M, Balamurali MN, Shanmugarajan D (2015) Decolorization of distillery spent wash using biopolymer synthesized by Pseudomonas aeruginosa isolated from tannery effluent. BioMed Research International DOI: http://dx.doi.org/10.1155/2015/195879.

Haas D, Défago G (2005) Biological control of soil-borne pathogens by fluorescent Pseudomonads. National Review Microbiology 3: 307-19.

Hansda A, Kumar V, Anshumali A, Usmani Z (2014) Phytoremediation of heavy metals contaminated soil using plant growth promoting rhizobacteria (PGPR): a current perspective. Recent Research in Science and Technology 6: 131-134.

Khan MU, Sessitsch A, Harris M, Fatima K, Imran A, Arslan M, ShabirG, Khan QM, Afzal M (2015) Cr-resistant rhizo- and endophytic bacteria associated with Prosopis juliflora and their potential as phytoremediation enhancing agents in metal-degraded soils. Frontiers Plant Science 5: 755-765.

Koller M (2017) Production of polyhydroxyalkanoate (PHA) biopolyesters by extremophiles. MOJ Polymer Science DOI: 10.15406/mojps.2017.01.00011.

Maity S, Das S, Samantaray DP (2017) Polyhydroxyalkanoates production by Zobellella species isolated from fish industrial effluents and its primary characterization. Journal of Environmental Biology 38: 1429-1434.

Mohapatra S, Maity S, Dash H, Das S, Pattnaik S, Rath CC, Samantaray DP (2017b) Bacillus and biopolymer: prospects \& challenges. Biochemistry and Biophysics Reports 12: 206-213.

Mohapatra S, Mohanta PR, Sarkar B, Daware A, Kumar C, Samantaray DP (2015) Production of polyhydroxyalkanoates (PHAs) by Bacillus strain isolated from waste water and its biochemical characterization. Proceedings of the National Academy of Sciences DOI: 10.1007/s40011-015-0626-6.

Mohapatra S, Samantaray DP, Samantaray SM (2014) Phylogenetic heterogeneity of the rhizospheric soil bacterial isolatesproducing PHAs revealed by comparative analysis of 16s-rRNA. International Journal of Current Microbiology and Applied Sciences 3: 680-690.

Mohapatra S, Samantaray DP, Samantaray SM, Mishra BB, Das S, Majumdar S, Pradhan SK, Rath SN, Rath CC, Akthar J, Achary KG (2016) Structural and thermal characterization of PHAs produced by Lysinibacillus sp. through submerged fermentation process. International Journal of Biological Macromolecules 93: 1161-1167.

Mohapatra S, Sarkar B, Samantaray DP, Daware A, Maity S, Pattnaik S, Bhattacharjee S (2017a) Bioconversion of fish solid waste into PHB using Bacillus subtilis based submerged fermentation process. Environmental Technology DOI: 
http://dx.doi.org/10.1080/09593330.2017.1291759.

Mohite B (2013) Isolation and characterization of indole acetic acid (IAA) producing bacteria from rhizospheric soil and its effect on plant growth. Journal of Soil Science and Plant Nutrition 13: 638-649.

Patel P, Shah R, Modi K (2017) Isolation and characterization of plant growth promoting potential of Acinetobacter sp. RSC7 isolated from Saccharum officinarumcultivar Co 671. Journal of Experimental Biology and Agricultural Sciences 5: 484-491.

Pattnaik S, Dash D, Samantaray DP (2017) Exploration of NPK activity showing chromium resistant bacteria from Sukinda mining area. International Journal of Current Microbiology and Applied Sciences 6: 535-542.

Patten CL, Glick BR (2002) Role of Pseudomonas putida indole acetic acid in development of the host plant root system. Applied and Environmental Microbiology 68: 3795-3801.

Samantaray DP, Mishra BB (2012) Effect of metal on hexavalent chromium reduction by Acinetobacter calcoaciticus. The Bioscan 7: 627-629.

Sobariu DL, Fertu DIT, Diaconu M, Pavel LV, Hlihor RM, Dragoi
EN, Curteanu S, Lenz M, Corvini PF, Gavrilescu M (2016) Rhizobacteria and plant symbiosis in heavy metal uptake and its implications for soil bioremediation. New Biotechnology 39: 125-134.

Upadhyay N, Verma S, Singh AP, Devi S, Vishwakarma K, Kumar K (2016) Soil ecophysiological and microbiological indices of soil health:a study of coal mining site in Sonbhadra, Uttar Pradesh. Journal of Soil Science and Plant Nutrition 6: 778-800.

Upadhyay N, Vishwakarma K, Singh J, Mishra M, Kumar V, Rani R, Mishra RK, Chauhan DK, Tripathi DK, Sharma S (2017) Tolerance and reduction of chromium(VI) by Bacillus sp. Mnu16 isolated from contaminated coal mining soil. Frontiers in Plant Science 8: 1-8.

Valverde A, Gonza'lez-Tirante M, Medina-Sierra M, Santa-Regina I, Garci'a- Sa'nchez A, García-Sánchez A, Igual JM (2011) Diversity and community structure of culturable arsenic resistant bacteria across a soil arsenic gradient at an abandoned tungsten-tin mining area. Chemosphere 85: 129-134.

Yu X, Li Y, Zhang C, Liu H, Liu J, Zheng W, Kang X, Leng X, Zhao K, Gu Y, Zhang X, Xiang Q, Chen Q (2014) Culturable heavy metalresistant and plant growth promoting bacteria in V-Ti magnetite mine tailing soil from Panzhihua, China. PLoS One DOI: https://doi.org/10.1371/journal.pone.0106618.

Journal of Experimental Biology and Agricultural Sciences 